\title{
Identification of Factors which Impact Towards Visit Intentions to Destination of Betawi Cultural Village Area
}

\author{
Aprila Safitri and Rina Astini
}

\section{ABSTRACT}

This research aims to determine and analyze those factors which influence the visit intentions to Betawi Cultural Village Tourism Area. This population was tourists who interested in visiting the tourist destinations of Betawi Cultural Village, while the sample in this research was 150 respondents. This research analyzed by Structural Equation Model (SEM) with assistance of LISREL 8.80 program to examine these hypotheses. The result shows that visit intention to Betawi Cultural Village Tourism Area was influenced by motivation to visit and image of destination, while eWOM did not impact the visit intention to Betawi Cultural Village Tourism Area.

Keywords: Travel Motivation, Destination Image, eWOM, Visit Intentions.

Submitted : February 6, 2021

Published : March 23, 2021

ISSN: 2507-1076

DOI: $10.24018 /$ ejbmr.2021.6.2.738

\section{Aprila Safitri *}

Mercu Buana University, Jakarta, Indonesia.

(e-mail: aprilia.safitriiiii @gmail.com) Rina Astini

Mercu Buana University, Jakarta, Indonesia.

*Corresponding Author

\section{INTRODUCTION}

Currently this tourism sector is one of the largest foreign exchange earners for Indonesia, written in 2014 it reached IDR 120 trillion and contributed around 11 million people to working in these opportunities. The tourism sector contributed to the national Gross Domestic Product (GDP) in 2014 which is $9 \%$ or IDR 946.09 trillion.

To encourage and develop these tourism sector, the government should be able to plan tourism development programs that carried out by various strategies such as developing tourist markets, developing tourism images, developing tourism marketing partnerships, and developing tourism promotions. All strategies planned by the government were carried out in order to achieve the tourism growth target. The targets of tourism development were increasing local businesses in the tourism business, increasing the income of people around tourist areas, and increasing the number of certified local workers.

To develop cultural tourism, it is necessary to have a tourist attraction that could invite more visitors to come to this cultural tourism. To be able to develop a cultural tourism area, it is necessary to have marketing management for this tourist area, so tourist attractions were visited by many tourists and earned lots of profits for the manager and the surrounding community.

According to this data by Betawi Cultural Village tourism manager in 2018 and 2019, it could be seen that there is an increase in the number of visits each year. However, the large increase in the number of visitors to Betawi Cultural Village area is still not significant in percentage, though when viewed more deeply the tourism potential of this tourist area is very large, seeing from the entrance ticket is free of charge, interesting artistic attractions, and various cultural tourism areas.

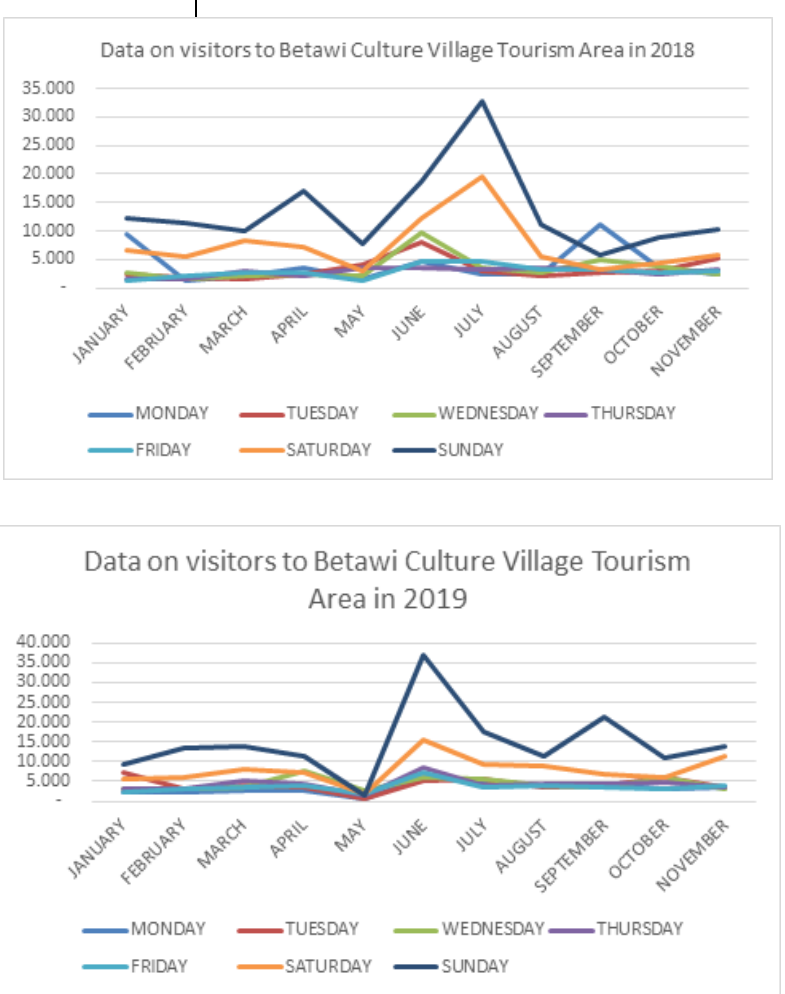

Fig. 1. The comparative ratio of visitors to the cultural village of Betawi in 2018 \& 2019.

In supporting this study, the writer made a survey of 30 of Jakarta's native residents to see what factors were considered or prompted the interest of those in visiting the betawi cultural village. Pre surveys have found that travel features, destination image and eWom are the 3 biggest factors which are thought to affect the intention in visiting the betawi cultural village.

Prior research by Chu and Luckanavanich [1] found that Travel Motivation, social media, and destination image had significant impact towards visit intentions. Krishnapillai and 
Ying [2] found that Electronic Word of Mouth (eWOM) have significant impact on visit intentions. Horng et al [3] found that Destination Familiarity influenced these visit intentions.

Based on these phenomena that have been stated above, these researchers were interested in conducting research on the influence of Travel Motivation, destination image and eWOM on tourist visit intentions to Betawi Cultural Village Tourism Area.

\section{THEORETICAL REVIEW}

\section{A. Travel Motivation}

According to Ahola in Chu \& Luckanavanich [1] Travel motivation is defined as the kind of satisfaction one expects and achieves by the journey. While plaque in Astini \& Sulistiwati [4] suggests that Travel Motivation is one set of needs that leads one to participate in the tourist activities. Furthermore, gas stations in Astini \& Sulistiwati [4] suggest that there are two dimensions to measure travel motivations: pull-ups and push surveys. Pull-offs are associated with these external forces projected to account for real goal options, while push pulls are associated with internal forces of the society themselves which explain their desire to go on vacation.

\section{B. Destination Image}

Destination images are the beliefs, attitudes, and impressions that people have when thinking about goals and perceptions related to goals in that person's mind. According to Echtner \& Brent Richie in Astini \& Sulistiyowati [4], destination image simply refers to the impression of a place or someone perception of certain area. Furthermore, they explained that there are four components of destination image, such as: functional characteristic attributes, holistic functional characteristics, psychological characteristics attributes and psychological-holistic characteristics.

\section{Electronic Word of Mouth (eWOM)}

According to Pride et al Krishnapillai \& Ying [2] WOM is a type of communication message that comes from outside the organization and the information generated usually outside the company's control. The increasing of internet use and social networking is also an important matter where currently the Word of Mouth is not only carried out by individually but could be in any form including the internet which is called as the Electronic Word of Mouth (eWOM). The effectiveness of Electronic Word of Mouth is more effective than Word of Mouth communication in this offline world, due to greater accessibility and high reach. (Chatterjee in [5]). There are four dimensions to measure these Electronic Word of Mouth (eWOM), such as Intensity in Electronic Word of Mouth, content, positive opinions and negative opinions [6].

\section{Visit Intention}

According to Kotler \& Armstrong [7], purchase decision process consists of five stages, namely knowing needs, seeking information, evaluating alternatives, purchase decisions and re-purchase behavior. Ferdinand in Putra \& Harijanto [8] stated that purchase interest was obtained from learning and thinking process that forms as a perception. Furthermore, he said that purchase interest could be identified in several factors, including through transactional interests, referential interests, preferential interests and exploration interests.

\section{E. Hypothesis and Conceptual Framework}

Based on these theories and previous research, the hypotheses in this research could be drawn such in below:

H1: Travel motivation variable had positive and significant impact towards variable of visit intention to the Betawi Cultural Village tourist area

H2: Destination image variable had positive and significant impact towards visit intention variable to the Betawi Cultural Village tourist area

H3: eWOM variable had positive and significant influence towards visit intentions to Betawi Cultural Village tourist area.

Based on this hypothesis, the authors compile a conceptual framework in this research as follows:

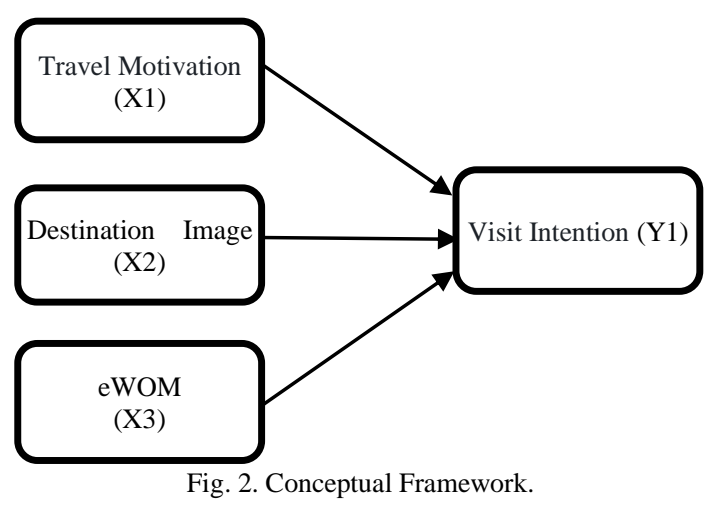

\section{RESEARCH METHODS}

This research used quantitative research methods by explanatory and survey approach. The independent variables in this research were travel motivation, destination image and eWOM, while the dependent variable is visit intention. The population in this research were tourists who were interested in visiting the Betawi Cultural Village Tourism Area. The sampling method used purposive sampling method with total sample of 150 respondents. This research analyzed by Structural Equation Model (SEM) with assist of LISREL 8.80 program to examine these hypotheses.

\section{RESULTS AND DisCUSSION}

\section{A. Respondent Acoustic Character}

Based on these characteristics of 150 respondents, the majority of tourists were male as many as 77 respondents $(51 \%),>30$ years old $(75 \%)$, have an income of between 5 20 million (59\%), and $100 \%$ come from Betawi culture. This illustrates that all tourists who visit are Betawi people, the majority who are male, who have sufficient income and excited in learning more about Betawi culture.

\section{B. Validity and Reliability Test}

Results from validity test by LISREL, all statements from research variables (travel motivation, destination image, 
eWOM and visit intention) have a Standardize Loading Factor value of $>0.5$, so it could be concluded if all statements were valid.
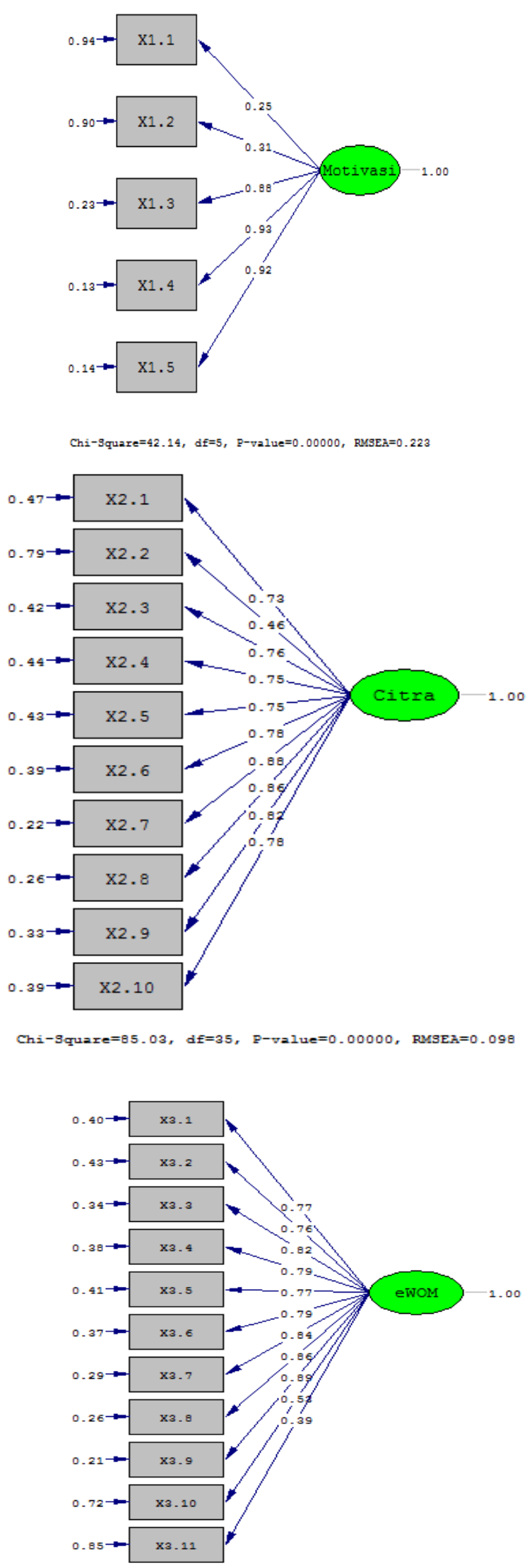

Chi-Square $=330.35$, df $=44, \mathrm{P}-\mathrm{value}=0.00000, \mathrm{RMSEA}=0.209$

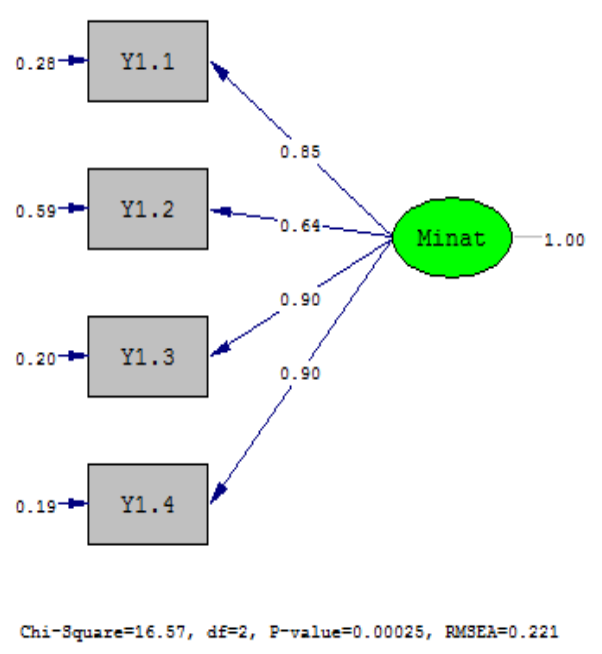

Fig. 3. SEM Measurement Test Results.

Then, based on these reliability test result, the destination motivation variable had CR value of 0.94 and $\mathrm{VE}$ value of 0.83; destination image variable had CR value of 0.94 with VE value of 0.62 ; eWOM variable had CR value of 0.94 , and $\mathrm{VE}$ value of 0.62 , visit intentions variable had $C R$ value of 0.90 and $\mathrm{VE}$ value of 0.69. According to the test results, it appears that all research variables have CR value of $>0.6$ and $\mathrm{VE}$ value $>0.5$, Meaning that all research variables were declared reliable.

\section{Test and Analysis of the Overall Fit of the Measurement Model}

There are two measurement categories used to examine the goodness of fit measurement model, namely the absolute fit measure and the incremental fit measure. Based on these test results, all indicators in the research variables get ChiSquare $=789.70, \mathrm{df}=293, \mathrm{P}-$ Value $=0.000$ and $\mathrm{RMSEA}=$ 0.107 , so the compatibility was Poor fit. (Where RMSEA < 0.08 was a good fit, RMSEA $<0.10$ marginal fit, and RMSEA > 0.10 poor-fit), so it is necessary to modify the model. After modification, it appears that the construct used to form a research model on the measurement of all variables has met the predetermined goodness of fit criteria.

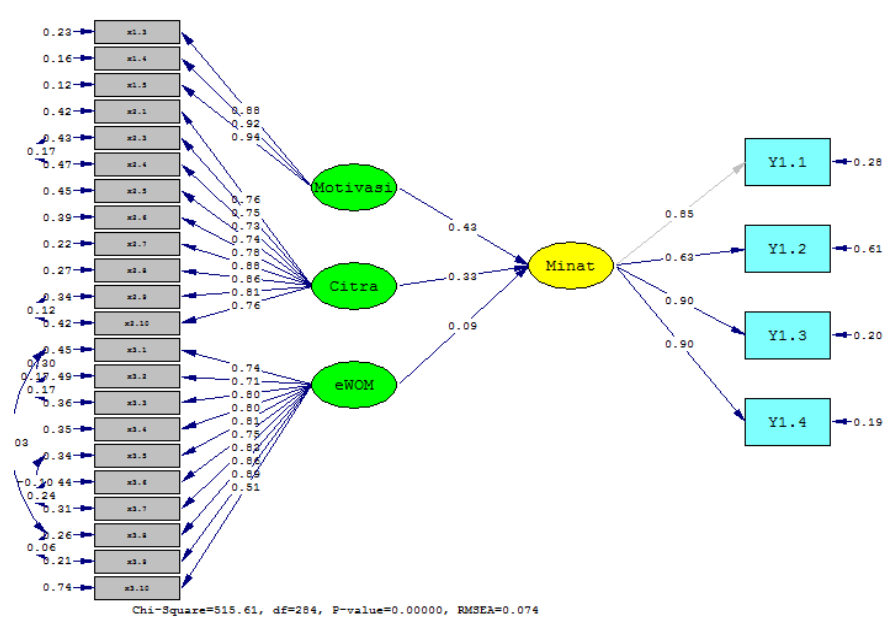

Fig. 4. Overall Variable Model.Hypothesis Tests

Based on the results of this SEM analysis, the R2 value was 0.60. Meaning that the tourists visit intention was influenced by Travel Motivation, destination image, and eWOM by $60 \%$. 


\section{Structural Equations}

$\begin{array}{cccc}\text { Minat }=0.43 * \text { Motivasi } & +0.33 * \text { Citra } & +0.093 * \text { eWOM, Errorvar. }=0.39, R^{2}=0.60 \\ (0.10) & (0.15) & (0.11) & (0.068) \\ 4.11 & 2.16 & 0.85 & 5.71\end{array}$

Fig. 5. Structural Equation Model Output.

Based on these SEM analysis results, it shows that:

1) The influence of travel motivation towards visit intentions has t-value $4.11>1.96$, with positive coefficient value of 0.43 . Meaning that Travel Motivation has a positive and significant impact towards visit intentions (H1 was accepted).

2) The influence of destination image on visit intentions had $\mathrm{t}$-value $=2.16>1.96$, with positive coefficient value of 0.33 . Meaning that the destination image has a positive and significant impact towards visit intentions (H2 was accepted).

3) The influence of eWOM on visit intentions has t-value $=0.85<1.96$, with positive coefficient value of 0.09 . Meaning that eWOM has no influence towards visit intentions (H3 was rejected).

TABLE 1. Hypothesis TeST RESUlts

\begin{tabular}{cccc}
\hline $\begin{array}{c}\text { Relationship Between } \\
\text { Construct }\end{array}$ & Estimates & t-Values & Information \\
\hline $\begin{array}{c}\text { Travel motivation -> } \\
\text { Visit intention }\end{array}$ & 0,43 & 4,11 & $\begin{array}{c}\text { Positive and } \\
\text { Significant } \\
\text { Destination image -> } \\
\text { Visit intention } \\
\text { eWOM -> Visit } \\
\text { intention }\end{array}$ \\
\hline
\end{tabular}
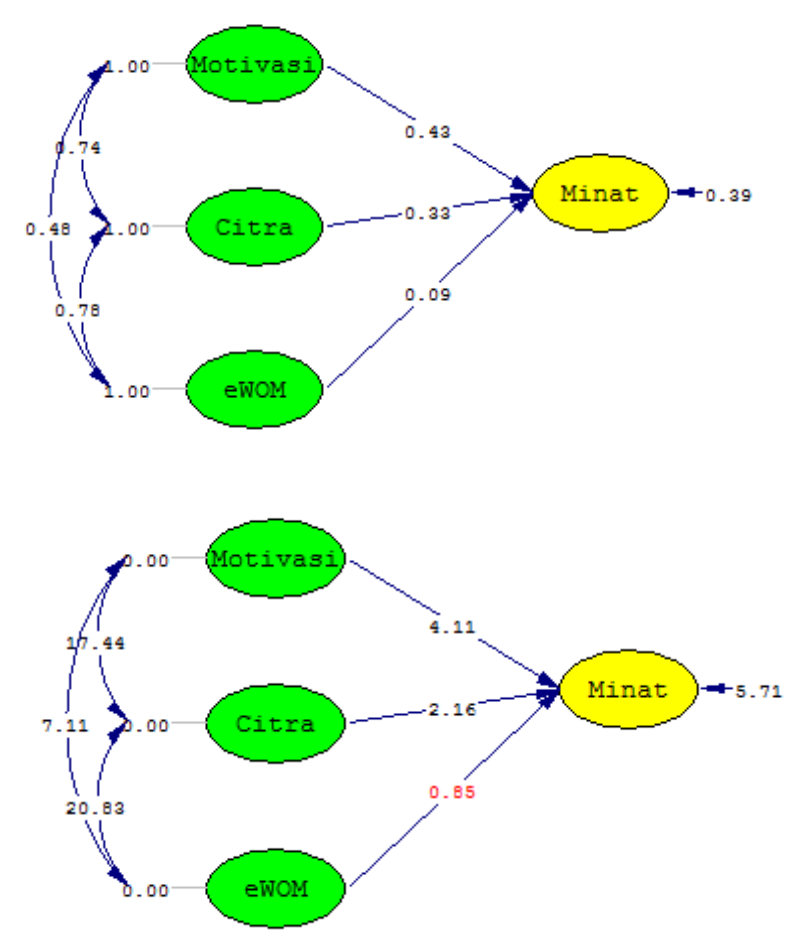

Fig. 6. Path Diagram of Structural Model Estimates and t-Value.

\section{CONCLUSION AND SUGGESTION}

\section{A. Conclusion}

According to these research results and its discussion above, the conclusions could be drawn as follows:
1) Travel Motivation has a positive and significant impact towards Visit Intentions.

2) Destination image has a positive and significant impact on Visit Intentions.

3) eWOM has no significant impact on Visit Intentions.

\section{B. Suggestion}

Based on the conclusions that authors described above, the suggestions from the authors included in these following recommendations:

1) In previous research, it was stated that eWOM had a significant impact on visit intentions however in these research results, it found that eWOM had no significant impact on visit intentions. As for further research, you can use a different subject than the ones used in this research.

2) For further research, you can add indicators or change respondents who were more specific to the eWOM indicator. Future studies could replace respondents with a certain age range to re-examine those respondents with a certain age range level.

\section{REFERENCES}

[1] Chu, C.P., \& Luckanavanich, S. (2018). The Influence of Social Media Use and Travel Motivation on The Perceived Destination Image and Travel Intention to Taiwan of The Thai People. International Journal of Arts and Commerce. 7(3).

[2] Krishnapillai, G., \& Ying, K.S. (2017). The Influence of ElectronicWord-of-Mouth on Travel Intention among Foreign Students in Malaysia: Does Gender Really Matter? International Reviewof Management and Marketing; EJ EconJournals, 7(1).

[3] Horng, J. S., Liu, C. H., Chou, H. Y., \& Tsai, C. Y. (2012) Understanding the impact of culinary brand equity and destination familiarity on travel intentions. Tourism Management, 33(4), 815824. http://doi.org/10.1016/j.tourman.2011.09.004.

[4] Astini, R. \& Sulistiyowati, I. (2015). Pengaruh Destination Image,Travel Motivaiton dan Kualitas Pelayanan Terhadap Kepuasan Pengunjung (Studi Kasus pada Wisatawan Nusantara Muslim di Pantai Carita Pandeglang Banten). Jurnal Ilmiah Manajemen dan Bisnis, 1(3).

[5] Jalilvand, M.R., Samiei, N., Dini, B., \& Manzari, P.Y. (2012). Examining the Structural Relationship of Electronic Word of Mouth, Destination Image, Tourist Attitude Toward Destination and Travel Intention: An Integrated Approach. Journal of Destination Marketing \& Management, 1:134-143.

[6] Goyette, I., Ricard, L., Bergeron, J., dan Marticotte, F. (2010). eWOM Scale: Word-of-Mouth Measurement Scale for e-Services Context. Canadian Journal of Administrative Sciences, 27(1), 5-23.

[7] Kotler, P \& Armstrong, G. (2012). Prinsip-prinsip Pemasaran. Edisi 13 Jilid satu. Erlangga. Jakarta.

[8] Teja, G., Putra, K., \& Harijanto, R. (2015). The Impact of Customer Value Proposition Towards Purchase Intention of Chesa Cup, Vol. 3, Issue 2.

[9] Ferdinand, A. (2006). Metode Penelitian Manajemen: Pedoman Penelitian Untuk Skripsi, Tesis, Disertai Ilmu Manajemen. Universitas Diponegoro: Semarang. 